\title{
EXPLORATORY RESEARCH FOR THE UNDERSTANDING OF THE ROLE PLAYED BY CULTURAL DESTINATION BRANDING IN THE ECONOMIC DEVELOPMENT OF TRIBAL INDIA - CASE STUDY OF JAUNSAR BAWAR TRIBAL REGION OF THE HIMALAYAS.
}

\author{
*1 Himanshu Chauhan, 2 Dr. Hemraj Verma \\ *1 Research Scholar - School of Liberal Arts \&amp; Management-FMS-DIT University \\ 2 Professor - School of Liberal Arts \&amp; Management - FMS - DIT University \\ *1 Email: himanshucha021@gmail.com
}

\begin{abstract}
Purpose: Cultural Destination Branding plays an important role to attract tourists. Jaunsar Bawar is endowed with historical and archaeological sites. The main purpose of this study is to identify the constituent elements of the overall image of the brand of Jaunsar Bawar's main heritage destinations by utilizing heritage, general, and unique images, and it proposes a model for branding Jaunsar Bawar's cultural \& heritage destinations. The region has all the potential to be an important cultural destination in the world. Well-planned branding strategies of these cultural destinations are a primary requirement to attract both foreign and domestic tourists. There are some barriers, which can impede successful cultural tourism marketing in Jaunsar Bawar. Lack of coordination among stakeholders, insufficient funding and providing less importance to the needs of the tourists can obstruct successful cultural destination branding. Developing creative promotional program, coordination among relevant stakeholders, conservation and protection of heritage sites and active participation of both private and public sector are necessary to implement cultural destination branding in Jaunsar Bawar.
\end{abstract}

Design/methodology/approach - This research is exploratory in nature and it uses the qualitative approach of primary research methodology by adopting a non-random stratified sampling method. To collect the data, approach of face-to-face semi-structured \& openended interviews of 19 local people as well as some from outside region but having specific knowledge about Jaunsar Bawar due to their detailed work done here was conducted.

Outcomes - The study shows that the people believe Destination Branding as an effective tool for the enhancement of the tourism in field related to Cultural \& Historical perspective of a tribal region like Jaunsar Bawar. The study also establishes that the various initiatives in field of creating a destination brand enhances the reputation and build a very strong, unique \& competitive brand in the minds of locals as well as in the minds of tourists/visitors who are planning or who have visited Jaunsar Bawar and this could result in the economic development of this Himalayan tribal region. 
Research implications - The findings of the study represent a significant contribution to the field of destination branding and will help practitioners to develop destination brand of their area of research and achieve competitive advantage in long-run which will create several business opportunities in the local area and thus gives competitive advantage in the long-run.

Research limitations - The study is confined only to the region of Jaunsar Bawar thus having a limited geographic scope of one region of one state of India. Therefore, studying other tribal regions of Himalayas may carry out further research.

Keywords: Jaunsar Bawar, Tourism, Cultural Destination Branding,, Economic Development, Cultural Tourism, Destination Brand.

\section{INTRODUCTION}

Visiting historical and cultural sites has always been a very fascinating \& a popular activity among tourists of all ages across the world. India is symbolized by its diversity of culture and heritage. The ancient past of India has helped the present and subsequent generations to have abundant of historical and cultural inheritances. The beautiful monuments and heritage sites in the country stand apart mutely today to paraphrase their story of India's great past before visitors. The Indian Government has recognized tourism as major engine of economic growth, which is visible from the heritage preservation efforts in the country. But there are so many places those still stands apart and require immediate attention. This study has been conducted in a tribal hilly area of Jaunsar Bawar of "Uttarakhand" settled in the lap of Western Himalaya, popularly as "Dev Bhoomi" or Land of Gods. Jaunsar Bawar has abundant heritage sites thus making it an ideal for tourism.

Heritage sites are an attractive destination in almost every country and for that reason the importance of heritage tourism is increasing day by day. Heritage tourism can be defined as visiting historical and archaeological sites for the purpose of acquiring knowledge or entertainment. Jaunsar Bawar is a tribal region in the Himalayan state of Uttarakhand in India and it has a rich culture, historical and archaeological sites which are very important heritage destinations in the world. Jaunsar Bawar has a great potential to become an important heritage destination in the world. Well- planned marketing program is essential to attract tourists in heritage destinations. Many developed and developing countries have successfully used marketing concepts and tools to attract heritage tourists in their countries. But heritage tourism marketing has not been given proper attention in Jaunsar Bawar and for that reason the number of heritage tourists is much less in this region. This study investigates the status, potential and barriers of heritage destination branding in Jaunsar Bawar.

\section{LITERATURE REVIEW}

Literature has recognized that history and culture are interlinked as "Culture is the modern way of using the elements of the past" (Timothy \& Boyd, 2003). "Heritage is what present society chooses to inherit and to pass on to the coming generations and history is what a 
historian regards as something which is worth recording” (Turnbridge \& Asworth, 1996).

The National Trust defines cultural tourism as "traveling to experience the places, artifacts, and activities that authentically represent the stories of the past and present. It includes cultural, historic and natural resources" (National Trust for Historic Preservation, 2008).

In addition to the physical objects and places of heritage there are various practices of heritage that are conserved or transferred from one generation to the next. These invisible or 'intangible' practices of heritage, such as language, culture, popular song, literature or dress, are as important in helping us to understand our society.

Culture is the things of value, which are inherited from our past generations. If the value is of community or national, we speak of our heritage. (Edgell, 2006).

According to Ahmed in 2006, Heritage places are those, which help an understanding of the past; enrich the present and which will be of value to the future generations. For the places of archeological and architectural values, it is the people and activities that form the cultural heritage.

Explaining Heritage tourism, Silberberg in 1995 defined that Heritage Tourism is a tool of economic development that achieves economic growth through attracting visitors from outside a host community, who are motivated wholly or in part by interest in the historical, artistic, scientific or lifestyle/heritage offerings of a community, region, group or institution.

In addition to the above, Chang in 1999 defined that; Heritage tourism can satisfy the cultural and leisure aspirations of the local community, providing residents with a greater sense of belonging to their homeland as well as intercultural awareness both within and outside a community.

Cultural and heritage tourists stay longer and spend more money than other kinds of travelers thus making such tourism an important economic development tool (Advisory Council on Historic Preservation, 2002).

Professor Simon Thurley, Institute of Historical Research, UK, has said and explained that Heritage is a production factor in an economy, thus it is an asset and not a liability, in relation to the European Study, Professor Thurley has mentioned and explained categorically that investing in cultural heritage will help strengthen Europe's economy, with the benefits extending far beyond tourism.

Professor Thurley's Heritage Cycle diagram (Fig. 1) as explained by Sarah May (2019), is actually a model where appreciation of heritage leads to a desire to protect it, which in turn leads to further appreciation for that heritage site and other cultural aspects related to it. This Heritage Cycle Diagram is such an important piece of study and a guide to the policy maker, and implementer, which could usher in a new era in field of converting heritage tourism as an important component of economy. 


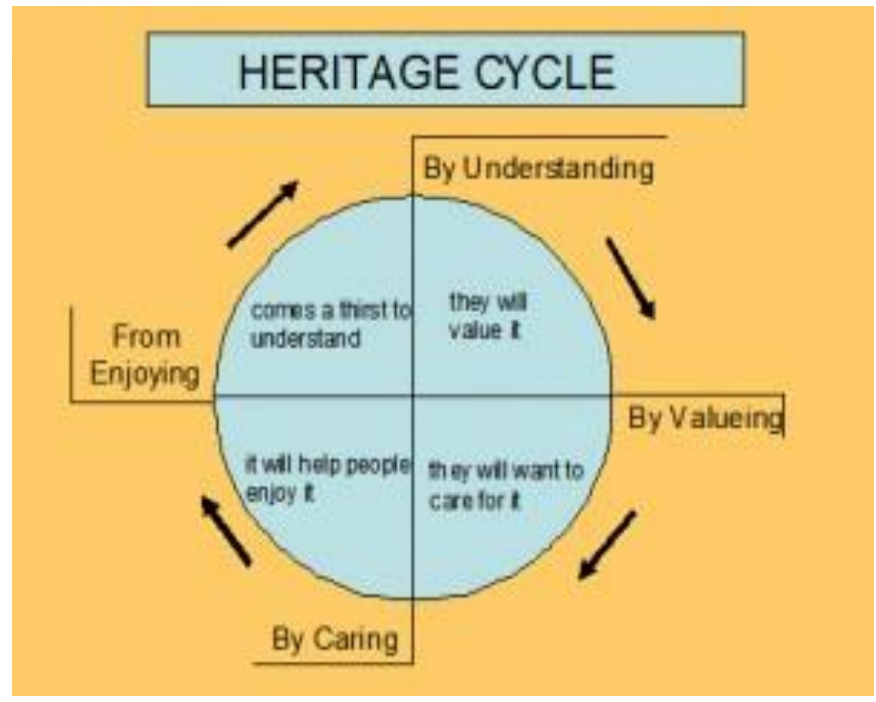

Figure 1: Heritage Cycle diagram

Across the world, several countries are increasingly becoming dependent on tourism, as it is one of the most rational and sustainable development choices that have the capability of creating employment to the communities and also acting as a main provision of foreign earnings to the economy (UNWTO, 2010 - Tourism and the Millennium Development Goals). Increasing competiveness amongst countries has also pushed the business capacity of the tourism industry to the level of, or, sometimes even exceeding trade commodities such as oil and food exports (UNWTO, 2011). While it is often the economic impacts of tourism that businesses and public organizations that are usually interested in (Stynes, 1999), the late twentieth century saw the emergence of environmental and socio-cultural impacts of tourism being controversial and critical issues discussed in tourism study.

Peak periods of tourism can benefit the economy of a country, however on the expense of the locals, who might have to pay for the higher prices of goods and services in the community, thus increasing their cost of living. The contributions of tourism to a country's economic benefits is relative to factors such as the availability of facilities and resources, the country's social and political-stability, the host communities' behavior towards tourist and the amount of investment injected by the government tourism projects and development (Youell, 1998). Heritage cycle actually helps in balancing these things, and if proper work is done in this field there is holistic development and preservation of Heritage \& Culture of the region.

\subsection{Objectives of the study}

- To enumerate the various opportunities related to cultural tourism in Jaunsar Bawar.

- To understand the benefits of cultural tourism to the tourism industry of Jaunsar Bawar.

- To analyze the factors enhancing the culture tourism in Jaunsar Bawar. 


\section{TYPE OF RESEARCH}

Descriptive research was used to study the potential of Cultural Tourism in Jaunsar Bawar Region.

\section{Methods of Data Collection}

Primary data - were collected from the natives and people doing research related to Jaunsar Bawar. Primary data was collected through interviews in the following ways:

\section{Personal Interviews}

The answer was sought to a set of pre-conceived questions through personal interviews and the data was collected in a structured way.

\section{Secondary Data}

It was collected by refereeing to the various other interviews or government television programs which talked in detail about the heritage \& culture of Jaunsar Bawar.

\section{DATA ANALYSIS \& INTERPRETATION}

The interviews conducted were important to understand the importance of Cultural \& Heritage of a region like Jaunsar Bawar, whether heritage tourism concept is a sustainable concept or no, if there could be noticeable growth in the heritage tourism of Jaunsar Bawar region then directly or indirectly there will be growth in the employment and opportunities of entrepreneurship in the region of Jaunsar Bawar. In the interviews of 20 respondents it was believed that Jaunsar Bawar has the potential to become a well-known name in field of Cultural \& Heritage tourism, popularity of local heritage sites like Ashok's Rock Edict in Kalsi, Ancient village of Jagatgram, Ancient temples of Lakhamandal as well as the culture of Jaunsar Bawar in the national or international tourism industry will definitely increase the sustainability of Cultural \& Heritage tourism as many of the travelers' in spite of their varied travelling purposes would love to explore the local culture $\&$ heritage to understand the area better and try to learn from them, at the same time respondents said that heritage \& cultural tourism could also impact the other form of lives as this will have cascading effects , travellers who are interested in heritage and culture tends to spend more time in one place to observe and understand the culture of a particular region, thus giving the other form of tourism or economy to get explored by such tourists and this will improve the economy of the region.

\section{OBSERVATIONS AND DISCUSSIONS}

The first and foremost observation is that the concept of Cultural tourism is not well established in the region of Jaunsar Bawar but it has the potential to become a very good rallying point for the region of Jaunsar Bawar. The awareness about Heritage \& Culture related to Jaunsar Bawar is still lacking. Jaunsar Bawar being an ancient cultural 
representative region of Himalayas, it is important that this region takes sincere efforts towards making local culture and heritage more popular among the inbound travelers of the region. Jaunsar Bawar is also known as "Land of Mahasu" hence it welcomes lot of religious tourism from Himachal, UP \& Uttarakhand. While doing this directly and indirectly Jaunsar Bawar opens lot of different opportunities in the tourism sector and service sector for employment and career at the same time it will open lot of opportunities for the entrepreneurship growth of the overall tourism industry. The observations are listed as follows

- All sectors of service and corporate industry people, all age group people believe that, Heritage \& Cultural tourism creates many opportunities for the employment.

- As a result of Cultural \& Heritage tourism different other business also get more opportunities of revenue generation, in effect the business grows and creates more job or employment for the locals.

- Local market \& local economy of the nearby region and many more business are indirectly growing as the tourism of the region develops and increases.

- 4.Infrastructure gets the boost in the local area as more and more people get attracted towards the culture and heritage, this in turns improves the living standard of the people with improvement in education, medical facility etc. which in turn helps in solving the problem of migration which is a big problem in the Himalayan region.

\section{FINDINGS}

Below mentioned were some of the interpretations that were drawn from the analysis:

- Majority of the respondents were agreeing upon the provision of a better exposure to the tourists and more advertisement will help the Cultural \& Heritage tourism to grow in the region of Jaunsar Bawar.

- The better amenities like good home-stays; at various tourist's destinations will improve the status of the Jaunsar Bawar tourism.

- The cultural \& heritage destination to undertake more aggressive marketing strategies to increase the visibility of the culture \& heritage of Jaunsar Bawar. This will make more people aware about the beautiful culture of Jaunsar and more people will come to explore it.

- Local people \& government should work towards working on the written part of the culture $\&$ heritage so that people could gain more information about this place.

- The key findings of the research says that the sustainability of the Heritage \& Cultural tourism industry and the popularity of local culture will bring more tourists to the region which indeed will get more revenues and the growth will open lot of many more employment opportunities 
- Many sides and periphery business to the tourism industry are growing because the Culture $\&$ heritage tourism industry is growing.

\section{RECOMMENDATIONS \& SUGGESTIONS}

- Create more awareness about the Cultural \& Heritage tourism and help the foodies to explore more and more as often as possible.

- Culture is a major part of any one's routine and life hence little extra efforts taken by the local people \& authorities can make the Jaunsar Bawar culture more and more popular

- It is important to organize different cultural and festive shows hosted in the region in a more professional way, which will bring lot of tourists to this region.

- It is important to provide the literature related to the heritage \& culture at the different tourist's destinations, this helps in giving more authenticity and importance to the region.

- A Jaunsar Bawar day, on $24^{\text {th }}$ June to be celebrated on a larger scale whereby giving platform to our local artists to show-case the rich culture of Jaunsar Bawar.

- Uttarakhand tourism Industry should undertake different promotional activities and organize cultural fairs and exhibitions to promote local heritage \& culture, this will bring a positive growth in their business.

- The local entrepreneurs of the Jaunsar Bawar region should do aggressive marketing and advertisement of their culture and heritage on different social media platform as well as at different events being organized in bigger cities like Dehradun, Delhi, Mumbai etc.

- State government of Uttarakhand should encourage new entrepreneurs with more affordable interest rate and facilities to come forward and venture different new ideas in field of cultural tourism of Jaunsar Bawar, Home-stay scheme of Jaunsar Bawar is one such scheme and this should be promoted more with technical support from the specialist so local people could showcase the culture of Jaunsar Bawar in a much better way.

\section{CONCLUSION}

As per the research and the analysis done by the researcher on the concern topic of Cultural \& Heritage tourism helps in generating employment and career opportunities following are the conclusions drawn. Cultural \& Heritage tourism growth is directly linked with the growth in employment generation of the region. All supporting business related to culture industry like food, clothes, ornaments, festivals etc. depend on the growth of Cultural \& Heritage tourism for the future prospects. Growth of Cultural \& Heritage of the region will help in improving 
the research in this field which in turns will improve the culture of the area thus making it more attractive to the inbound tourists as well as give more confidence to the local residents to showcase their rich culture to the world.

\section{REFERENCE}

[1]. Allen, G. (2007). Place branding: New tools for economic development. Design Management Review, 18(2), 60-68.

[2]. Almeyda-Ibáñez, M., \& George, B. P. (2017). The evolution of destination branding: A review of branding literature in tourism. Journal of Tourism, Heritage \& Services Marketing, 3(1), 9-17.

[3]. Ashworth, G. (2010). Should we brand places? Journal of Town and City Management, $1,248-252$.

[4]. Blain, C., Levy, S. E., \& Ritchie, J. B. (2005). Destination branding: Insights and practices from destination management organizations. Journal of travel research, 43(4), 328-338.

[5]. Caprara, G. V., C. Barbaranelli and G. Guido (2001). "Brand Personality: How to Make the Metaphor Fit?” Journal of Economic Psychology, 22: 377-395.

[6]. Chauhan, A. (2020). Destination Image of Selected Tourist Destinations Measurement Analysis and Implications.

[7]. Cleave, E., Arku, G., Sadler, R., \& Gilliland, J. (2016). The role of place branding in local and regional economic development: bridging the gap between policy and practicality. Regional Studies, Regional Science, 3(1), 207-228.

[8]. Crask, M. R., and A. L. Henry (1990). "A Positioning-Based Decision Model for Selecting Advertising Messages.” Journal of Advertising Research, 30 (4): 32-38.

[9]. Colin Michael Hall (1997), dissonant heritage: The management of the past as a resource in conflict, Annals of Tourism research 24(2): 496-498

[10]. Dr. Alok Kumar (2017), Cultural and Heritage Tourism: A Tool For Sustainable Development

[11]. Mahmudul Hasan, Md. Imrul (2014). Heritage Tourism Marketing: Status, Prospects and Barriers

[12]. Raymond A. Rosenfeld (2008), Cultural \& Heritage Tourism

[13]. Sarah May (2020) Heritage, endangerment and participation: alternative futures in the Lake District, International Journal of Heritage Studies, 26:1, 71-86, DOI: 10.1080/13527258.2019.1620827

[14].http://www.cultureindevelopment.nl/cultural_heritage/what_is_cultural_heritage

[15]. https://nevadapreservation.org/heritage-tourism-planning/ 